\title{
Trends in asthma and hay fever in general practice in the United Kingdom 1976-83
}

\author{
JON G AYRES \\ From the Department of Respiratory Medicine, East Birmingham Hospital, Birmingham
}

ABSTRACT Weekly returns from the Royal College of General Practitioners research unit indicate that the attack rates for acute asthmatic episodes show a summer peak followed by an autumn peak in five out of the eight years studied, a summer peak alone in one year, and no discernible peak in two years. The autumn peaks coincide precisely with the rise in acute bronchitis attack rates, suggesting that autumnal asthma may be due to viral infections occurring against the background of bronchial hyperreactivity induced by summer pollen exposure. These data might also suggest that autumnal asthma is more likely to be diagnosed as acute bronchitis. Hay fever attack rates coincide with the rise in grass pollen counts, whereas the summer asthma peak is delayed by two to three weeks after the pollen peak.

Asthma and hayfever are common conditions, seen frequently in general practice. Morbidity from asthma is high, with many days of schooling ${ }^{12}$ and work lost in England and Wales-the latter having increased from around 2 million a year in $1968^{3}$ to over four million a year in 1982 (Department of Health and Social Security, personal communication). Epidemiological studies of asthma in Britain have, however, in general concentrated on hospital admissions (Hospital Activity Analysis) ${ }^{4}$ or mortality. ${ }^{56}$ There have been several studies of asthma in individual practices in England, ${ }^{7}$ which had the benefit of being performed where the general practitioners had a particular interest in asthma. The data obtained by the Royal College of General Practitioners (RCGP) research unit from its weekly returns can be used as indicators for assessing national trends in acute bronchitis. ${ }^{8}$ Data are also available for asthma and hay fever from 1976, and the present study was performed to assess any seasonal changes in asthma attack rates and to determine whether there has been evidence of an increase in annual attack rates for either condition since 1976.

\section{Methods}

The source of the data examined in this study has been described fully elsewhere. ${ }^{89}$ In summary, weekly

Address for reprint requests: Dr JG Ayres, Department of Thoracic Medicine, East Birmingham Hospital, Birmingham B9 5ST.

Accepted 11 September 1985 returns from 41 general practices in the United Kingdom are sent to the RCGP research unit, at Harborne in Birmingham, recording the number of "events" in a series of diagnostic categories, including acute respiratory conditions, seen in each practice over the previous week. Asthma and hay fever rates are given per 100000 population at risk for all ages from 1976 to 1983 for asthma and from 1981 to 1983 for hay fever. The data for 1983 are also presented in five age bands $(0-4,5-14,15-44,45-64,65$ and over). There is no information available about the distribution of attack rates between the sexes by age.

Grass pollen counts were obtained from the National Hayfever and Pollen Counting Bureau Station at Dudley, West Midlands. This is near the geographical centre of the area covered and the counts are used to represent the average for the whole country.

To bring out any consistent but slight cyclical trends occurring at the same time of year over the years studied, the data for asthma have been summed for all years. If the trends are not consistent from year to year, however, then any individual yearly peaks will be smoothed out or even lost altogether by this kind of analysis.

\section{Results}

ALL AGES

Hay fever (ICD No 477; available for 1981-3 only) There is a unimodal peak attack rate occurring in June of each year (fig 1, table 1). These peaks 
Attack rates/

Pollen count

100000

(mean weekly counts $/ \mathrm{m}^{3}$ )
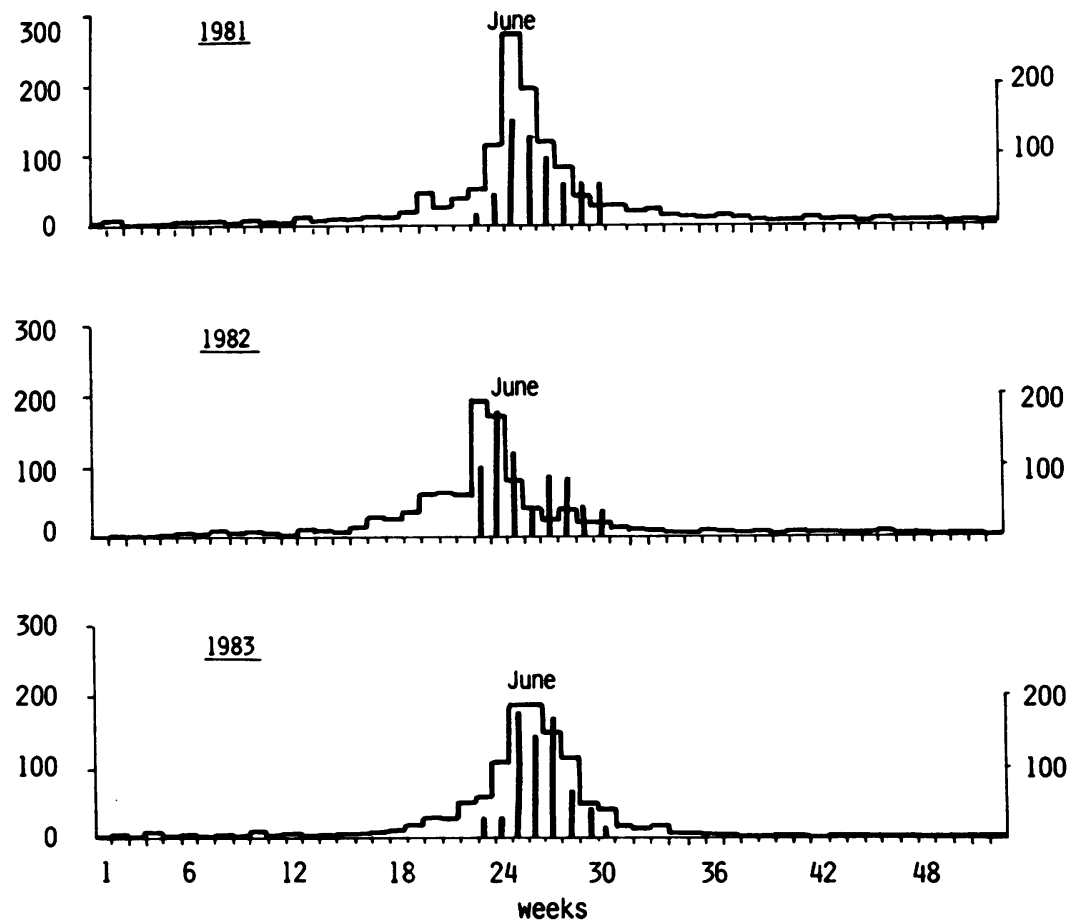

Fig 1 Weekly attack rates per 100000 for hay fever (all ages) for 1981, 1982, and 1983 and grass pollen counts $/ \mathrm{m}^{3}$ per week (Dudley, West Midlands). | Pollen counts; $几$ hay fever attack rates.

coincide precisely with the high grass pollen counts (fig 1).

Acute asthmatic episode (ICD No 493) In 1976, $1979,1981,1982$, and 1983 both summer and autumn peaks were seen, which are made more apparent when the data from 1976 to 1983 are summed (fig 2). In 1977 a summer peak alone was seen but in 1978 and 1980 there were no seasonal trends, peak weeks occurring in the fifth (early February) and 10th (early March) weeks respectively, weeks in which in other

Table 1 Population at risk, maximum and minimum weekly attack rates per 100000 , and mean weekly attack rate per annum for asthma and hay fever, 1976-83

\begin{tabular}{|c|c|c|c|c|c|c|}
\hline \multirow[b]{2}{*}{ Year } & \multirow[b]{2}{*}{$\begin{array}{l}\text { Population } \\
\text { at risk }\end{array}$} & \multicolumn{3}{|l|}{ Asthma } & \multicolumn{2}{|l|}{ Hay fever } \\
\hline & & $\begin{array}{l}\text { Max weekly } \\
\text { rate (week } \\
\text { of occurrence) }\end{array}$ & $\begin{array}{l}\text { Min weekly } \\
\text { rate (week } \\
\text { of occurrence) }\end{array}$ & $\begin{array}{l}\text { Mean weekly } \\
\text { rates pa }\end{array}$ & $\begin{array}{l}\text { Max weekly } \\
\text { rate (week } \\
\text { of occurrence) }\end{array}$ & $\begin{array}{l}\text { Min weekly } \\
\text { rate (week } \\
\text { of occurrence }\end{array}$ \\
\hline $\begin{array}{l}1976 \\
1977 \\
1978\end{array}$ & $\begin{array}{l}189346 \\
171703 \\
164784\end{array}$ & $\begin{array}{l}21.7(26) \\
17.5(28) \\
25.4(5)\end{array}$ & $\begin{array}{l}5.0(12,35) \\
5.3(23) \\
6.4(12)\end{array}$ & $\begin{array}{l}10.2 \\
10.4 \\
14.4\end{array}$ & & \\
\hline $\begin{array}{l}1979 \\
1980 \\
1981 \\
1982 \\
1983\end{array}$ & $\begin{array}{l}175440 \\
202846 \\
196362 \\
195022 \\
204676\end{array}$ & $\begin{array}{l}27.3(38) \\
29.0(10) \\
38.1(28) \\
30.9(41) \\
42.0(28)\end{array}$ & $\begin{array}{c}9 t h \text { ICD cod } \\
7.2(18) \\
11.8(52) \\
7.0(16) \\
5.1(52) \\
7.0(52)\end{array}$ & $\begin{array}{l}\text { evision } \\
16.3 \\
17.9 \\
17.9 \\
18.1 \\
17.3\end{array}$ & $\begin{array}{l}271.6(25) \\
190.0(23) \\
198.0(25)\end{array}$ & $\begin{array}{l}0(52) \\
0(\mathrm{~N}) \\
0(49,51,52)\end{array}$ \\
\hline
\end{tabular}

$\mathbf{N}=$ occurring in many weeks. 
Trends in asthma and hay fever in general practice in the United Kingdom 1976-83

Summed Rates

per 100000

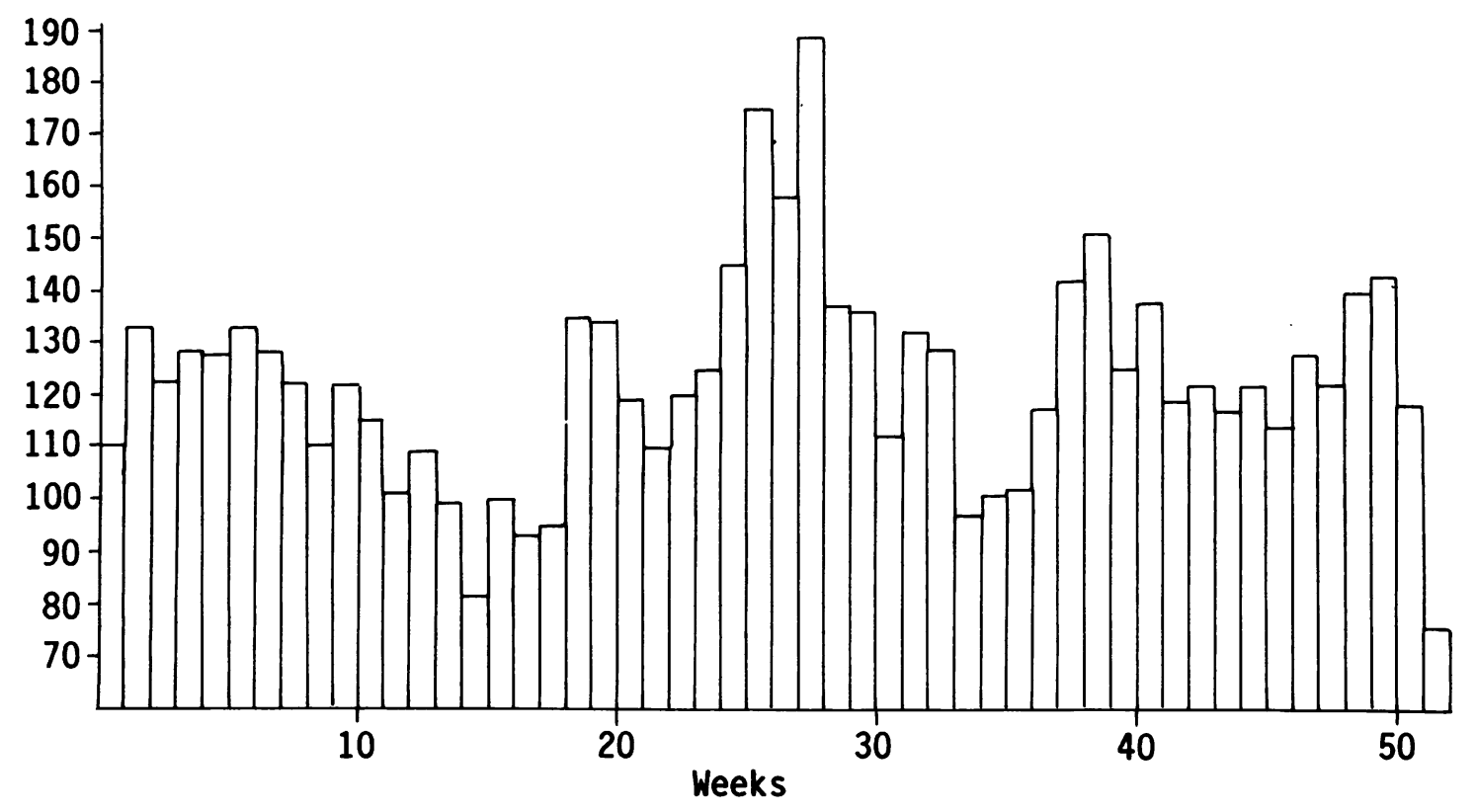

Fig 2 Summed weekly attack rates per 100000 for all ages for asthma from 1976 to 1983.

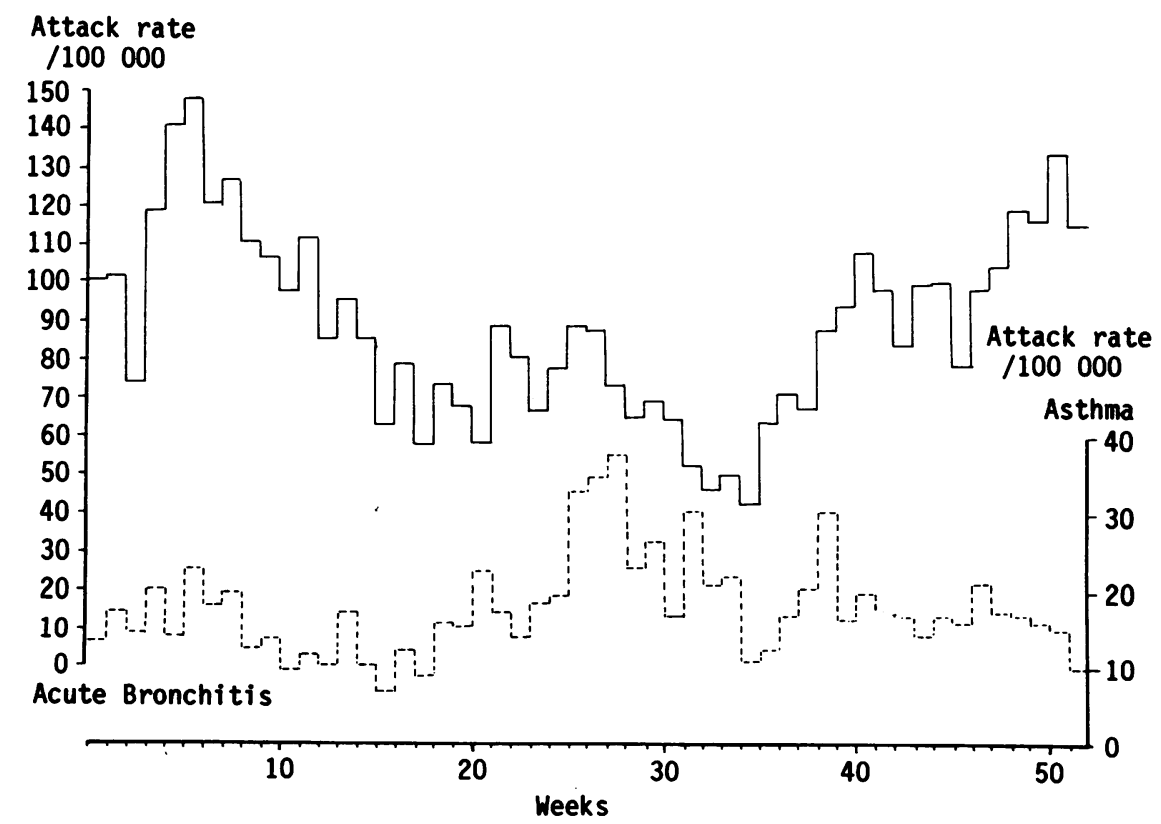

Fig 3 Attack rates per 100000 for acute bronchitis ) and for asthma (- - - ) for all ages (1981). 
Table 2 Age banded data for asthma and hay fever for 1983 (rates/100000 population at risk)

\begin{tabular}{|c|c|c|c|c|c|c|}
\hline \multirow[b]{2}{*}{$\begin{array}{l}\text { Age } \\
(y)\end{array}$} & \multirow[b]{2}{*}{$\begin{array}{l}\text { Population } \\
\text { at risk* }\end{array}$} & \multicolumn{3}{|l|}{ Asthma } & \multicolumn{2}{|l|}{ Hay fever } \\
\hline & & $\begin{array}{l}\text { Max weekly } \\
\text { rate (week } \\
\text { of occurrence) }\end{array}$ & $\begin{array}{l}\text { Min weekly } \\
\text { rate (week } \\
\text { of occurrence) }\end{array}$ & $\begin{array}{l}\text { Mean weekly } \\
\text { rate p.a. }\end{array}$ & $\begin{array}{l}\text { Max weekly } \\
\text { rate (week } \\
\text { of occurrence) }\end{array}$ & $\begin{array}{l}\text { Min weekly } \\
\text { rate (week } \\
\text { of occurrence }\end{array}$ \\
\hline $\begin{array}{l}0-4 \\
5-14 \\
15-44 \\
45-64 \\
65^{*}\end{array}$ & $\begin{array}{l}11895 \\
28766 \\
91103 \\
42334 \\
30568\end{array}$ & $\begin{array}{l}78(11) \\
99(28) \\
38(28) \\
28(29) \\
25(3)\end{array}$ & $\begin{array}{l}0(14,33,51) \\
7(5) \\
4(50) \\
0(37) \\
0(21,27,37)\end{array}$ & $\begin{array}{l}35.6 \\
35.7 \\
13.4 \\
11.5 \\
10.1\end{array}$ & $\begin{array}{r}142(25) \\
448(26) \\
241(26) \\
56(26) \\
18(22)\end{array}$ & $\begin{array}{l}0(\mathrm{~N}) \\
0(\mathrm{~N}) \\
0(44,48) \\
0(\mathrm{~N}) \\
0(\mathrm{~N})\end{array}$ \\
\hline
\end{tabular}

* 10 patients not included because age not recorded.

$\mathrm{N}-$ occurring in many weeks.

years there were no such peaks. In 1976, 1979, 1981, 1982 , and 1983 there were rises in asthma notifications from week 36 , coinciding exactly with a rise in acute bronchitis notifications. ${ }^{8}$ The data for 1981 are shown in figure 3 as an example. This exam- ple also shows a rise in acute bronchitis rates at the height of the summer asthma peak. There is an increase in the crude average weekly attack rates for asthma from 1976 to 1980 , but since then the rates have remained steady (table 1 ).
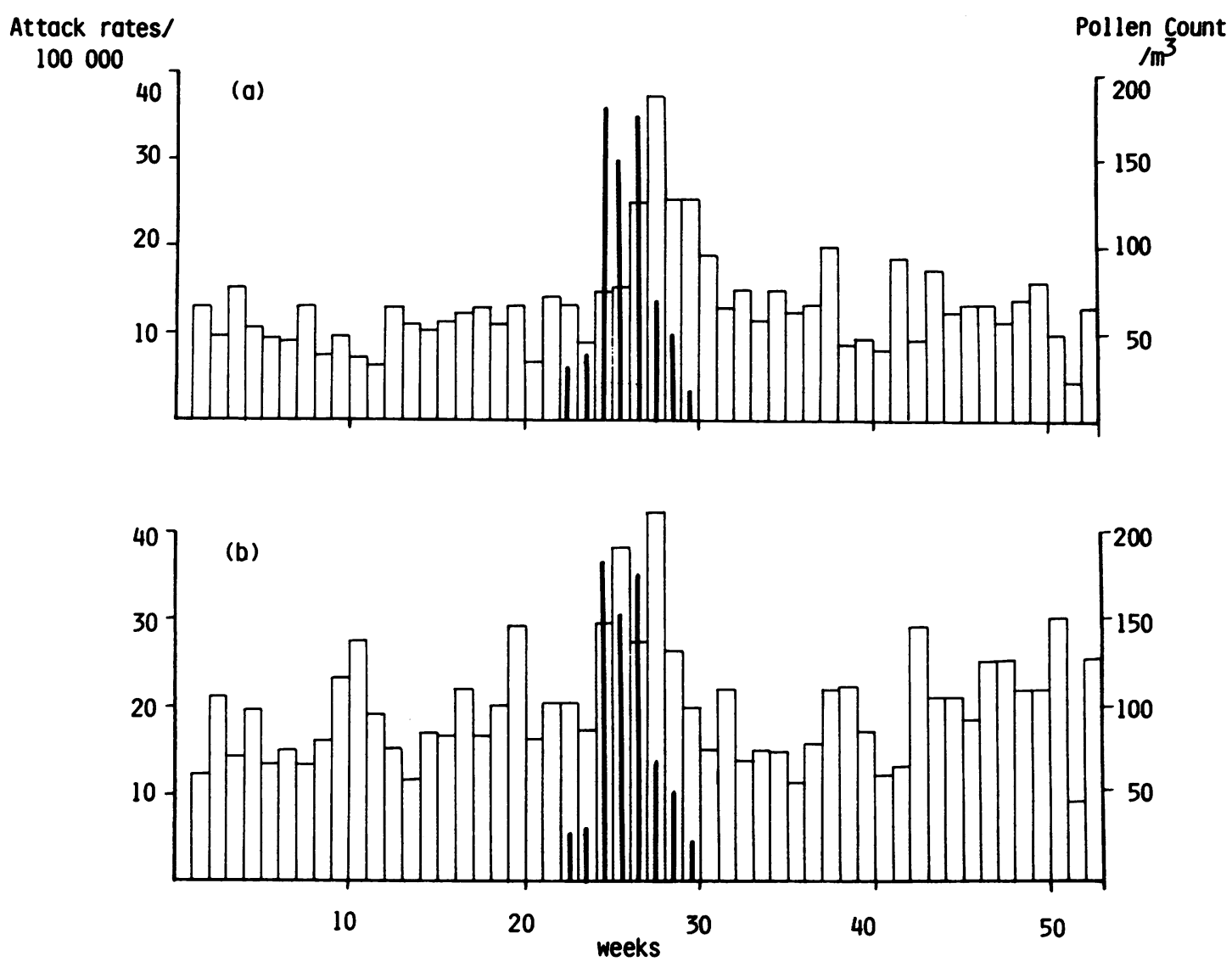

Fig 4 Weekly attack rates per 100000 for asthma for (a) the 15-44 age group and (b) all other ages, with grass pollen counts $/ \mathrm{m}^{3} /$ week (1983). I Pollen counts; $\square$ asthma attack rates. 
AGE BANDED DATA (1983 only)

Hay fever (table 2) The summer peak is obvious in age groups up to 45 years (table 2). At older ages the numbers are small but no clear peaks are seen, although the weeks of maximum attack are in the summer.

Asthma (table 2, fig 4) The 15-44 year age group is regarded as being less affected by non-asthmatic conditions as it excludes the younger patients, in whom a diagnosis of bronchiolitis or bronchitis may confuse the diagnostic picture, and the older age groups, where chronic bronchitis and emphysema are common. ${ }^{10}$

There is little difference between the pattern of attack rates for all ages and that for the 15-44 age group. In this group there is an increase in attack rate from around 10 per 100000 to a maximum of 38 per 100000 at week 27 , returning to 10 per 100000 at week 31 , where it remains through the winter (apart from two weeks in the autumn with rates of 18 and 20 per 100000 ). The asthma peak appears to be delayed by two to three weeks after the peak pollen count.

\section{Discussion}

The main perturbing influence affecting these data is the diagnostic individuality of each general practitioner, particularly where asthma is concerned, since the doctors use their own diagnostic criteria without a common set of guidelines. Scadding's definition of asthma ${ }^{11}$ has its limitations, one of which is that no mention is made of the clinical picture as seen by a physician. So a patient with cough, a common symptom of asthma, ${ }^{12}$ may consequently be regarded as having acute bronchitis rather than asthma. This will result in underdiagnosis of asthma, ${ }^{213}$ and consequent underestimation of asthma attack and prevalence rates, and also in the prescription of inappropriate treatment being prescribed. ${ }^{14}$ In the case of hay fever, on the other hand, there is likely to be high diagnostic consistency among general practitioners, so that the data may be useful for following regional as well as national trends for this particular condition.

The data for hay fever show a clearcut, unimodal summer peak, maximal at around week 25 , in a remarkably constant manner. This is closely related to the increase in grass pollen counts. There is usually a two week phase shift in pollen counts from Devon to Scotland in any given year, so it is reasonable to use the Dudley counts as representing the count for the whole country. A very small proportion of the patients presumably had perennial rhinitis, accounting for the consistently low level winter rates. In the extremes of life the total numbers per week are so small that little can be drawn from the data apart from the fact that the condition would appear to be infrequently diagnosed. A recent report from Denmark, ${ }^{15}$ covering a population at risk of around 500000 in general practice, also noticed the peak hay fever period to be weeks 21-26. They measured birch pollen as well as grass pollen and believed that birch pollen was more likely to cause problems in the older patients, but this will need further confirmation.

The data on asthma show that in some years appreciable summer peaks occur but these are not seen in the $0-4$ and $65+$ age bands in the one year analysed for age. These peaks are likely to be due to release of grass pollen but, interestingly, the hay fever peak, which is undoubtedly related to grass pollen, precedes the summer asthma peaks by some two to three weeks. This may represent a difference in disease mechanisms or a tendency for patients with hay fever to present immediately their symptoms start to occur, the asthmatics tending to delay before going to their general practitioner as they have treatment already available, which they continue to use, possibly at increased doses, until they consider that their symptoms have not responded.

As discussed elsewhere, ${ }^{8}$ these data cannot identify those individual patients who attend with recurrent attacks of asthma. This might confer a bias on acute asthma attack rates, particularly if a large proportion of recurrent attenders presented in summer and autumn. This would not, however, affect any interpretation of the existence of the seasonal peaks, although it would affect the magnitude of the peaks if this was being assessed. The seasonal distribution of asthma attendances is in direct contrast to findings from hospital based studies, which show maximal rates of attendance at hospital emergency departments in the autumn in the United States ${ }^{16}$ and in England and Wales both for children ${ }^{4}$ and for adults (Khot, personal communication), and to the finding that deaths from asthma are maximal in the autumn quarter. ${ }^{5}$ This might suggest that summer asthma is less likely to be fatal or that autumn admissions are due either to chronic, refractory cases of summer asthma or to autumnal aetiological causes. The figures from general practice show that autumn peaks of asthma are consistently preceded by a summer peak, the former coinciding with the start of the autumn rise in acute bronchitis rates. Provided that there is no regional difference to explain these dual peaks, this could suggest that a summer of sensitisation is likely to leave asthmatic patients more susceptible to the effects of autumnal viral infections. The suggestion that viruses are responsible for autumnal asthma has been made before, ${ }^{1718}$ with the additional possibility that such viral infections may perpetuate the problem by increasing bronchial hyperreactivity. ${ }^{19}$ Other suggestions for the autumnal rise are changes in the weather ${ }^{2021}$ and variation in 
the levels of house dust mites. ${ }^{22}$ The theory that release of fungal spores may play a part is more tentative. ${ }^{23}$

The slight rise in acute bronchitis rates associated with the summer rise in asthma may give further evidence to the belief that asthma is being misdiagnosed as acute bronchitis. This may be compounded by regarding the same symptoms as due to "allergy" in the summer and "infection" in the winter. The mean weekly attack rates for asthma in 1983 are highest up to the age of 14 and then fall away with age. This is consistent with the work from the United States, ${ }^{24}$ showing that a diagnosis of asthma is more likely to be made in young, non-smoking, atopic individuals but that in older patients who smoke cigarettes a diagnosis of bronchitis is more likely to be made.

There has been little change in the annual average weekly attack rates for asthma over the last four years according to these data. This is interesting, given that the analysis of Health Activity Analysis data by Khot et $\mathrm{al}^{4}$ suggests that there has been an increasing trend in admissions to hospital for asthma in children over the last eight years. One possible explanation is that the clinical threshold for admitting patients with asthma has been lowered over this period. Alternatively, patients may be developing worse asthma even though the prevalence remains unchanged. A third possibility is that asthma is being diagnosed more in hospital than in general practice.

I gratefully acknowledge the help and guidance of Dr DL Crombie, Mrs C Norbury, and the staff of the Royal College of General Practitioners research unit in the compilation of data for this study. I would like to thank Dr VH Springett for his advice in writing the paper, and Mrs Pamela Jackson for secretarial assistance.

\section{References}

1 Hoekelman RA. Allergy in childhood. A pediatrician's viewpoint. Pediatr Clin North Am 1974;21:5-21.

2 Speight ANP, Lee DA, Hey EN. Underdiagnosis and undertreatment of asthma in childhood. $\mathrm{Br} \mathrm{Med} \mathrm{J}$ 1983;286:1253-6.

3 Springett VH. Hospital Admission and Absence from Work Attributed to Asthma. Br Med J 1969;i:402-3.

4 Khot A, Burn R, Evans N, Lenney C, Lenney W. Seasonal variation and time trends in childhood asthma in England and Wales, 1975-1981. Br Med J 1984;289:235-7.

5 Inman WHW, Adelstein AM. Rise and fall of asthma mortality in England and Wales in relation to use of pressurised aerosols. Lancet 1969;ii:279-85.

6 British Thoracic Association. Death from asthma in two regions of England. $\mathrm{Br} \mathrm{Med} J$ 1982;285:1251-5.

7 Gregg I. Epidemiological aspects. In: Clark TJH, Godfrey S, eds. Asthma. 2nd ed. London: Chapman \& Hall, 1983.

8 Ayres JG. Seasonal pattern of acute bronchitis in general practice in the United Kingdom, 1976-83. Thorax 1986; 41:106-10.

9 Fleming DM, Crombie DL. The incidence of common infectious diseases: the Weekly Returns Service of the Royal College of General Practitioners. Health Trends 1985;17:13-6.

10 Subcommittee of the British Thoracic Association Research Committee. Accuracy of death certificates in bronchial asthma. Thorax 1984;39:505-9.

11 Scadding JG. Definition and clinical categories of asthma. In: Clark TJH, Godfrey S, eds. Asthma 2nd ed. London: Chapman and Hall, 1983: 1-11.

12 Corrao WM, Braman SS, Irwin RS. Chronic cough as the sole presenting manifestation of bronchial asthma. $N$ Engl J Med 1979;300:633-7.

13 Anderson HR, Bailey PA, Cooper JS, Palmer JC. Influence of morbidity, illness label, and social family and health service factors on drug treatment. Lancet 1981;ii:1030-2.

14 Horn CR, Cochrane GM. Undertreatment of asthma in general practice [abstract]. Thorax 1984;39:687.

15 Pederson PA, Weeks ER. Allergic rhinitis in Danish general practice. Allergy 1984;39:165-70.

16 Goldstein IF, Currie B. Seasonal patterns of asthma: a clue to aetiology. Environ Res 1984;33:201-15.

17 Horn MEC, Brown E, Gregg I, Yealland SJ, Inglis JM. Respiratory viral infection in childhood. A survey in general practice, Roehampton 1967-1972. J Hyg 1975;74:157-68.

18 Welliver RC. Upper respiratory infections in asthma. $J$ Allergy Clin Immunol 1983;72:341-6.

19 Empey DW, Laitinen LA, Jacobs L, Gold WM, Nadel JA. Mechanisms of bronchial hyperreactivity in normal subjects after upper respiratory infection. Am Rev Respir Dis 1976;113:131-9.

20 Goldstein I. Weather patterns and asthma epidemics in New York City and New Orleans, USA. Int J Biometeorol 1981;68:327-46.

21 Greenberg L, Field F, Reed JI, Erhardt CL. Asthma and temperature change. An epidemiological study of emergency clinic visits for asthma in three large New York Hospitals. Arch Environ Health 1964;8:642-7.

22 van Bronswijk JEMH. Dermatophagoides pteronysssinus (Trouessant 1897) in mattress and floor dust in a temperature climate. J Med Entomol 1973;10:63-70.

23 Salvaggio J, Aukrust L. Mold induced asthma. J Allergy Clin Immunol 1981;68:327-46.

24 Dodge RR, Burrows B. The prevalence and incidence of asthma and asthma-like symptoms in a general population sample. Am Rev Respir Dis 1980;122:567-75. 